\title{
How urban and rural birds respond to the colour of bird feeders?
}

\author{
Artur Golawski $^{1}\left[\right.$ ] $\cdot$ Hubert Sytykiewicz ${ }^{1}$ (i)
}

Received: 9 January 2021 / Revised: 13 March 2021 / Accepted: 24 June 2021 / Published online: 2 July 2021

(c) The Author(s) 2021

\begin{abstract}
Birds can adapt to urban areas by modifying their foraging behaviours to exploit novel urban food sources, which are far more diverse than in the country. Neophobia, the fear of novelty, can lead to missed new sources of food. Urban populations of birds usually display a lesser level of neophobia than rural populations. We examined the response of birds in urban and rural habitats to the presence of new feeders. One feeder was green (the colour of preference, according to the literature), the other one was yellow (the colour avoided); feeders of these colours are not normally used in the study area, where the colour of bird feeders is usually the natural colour of wood. We hypothesised that the yellow feeder was more likely to be avoided by rural than urban birds because of the greater neophobia exhibited by the former. During the wintering season, we carried out 22 experiments in towns and 21 in villages in east-central Poland. The interaction between habitat and feeder colour was close to zero (number of visits to a feeder, choice of first feeder). However, we did find a smaller number of visits to yellow feeders and more frequent visits to feeders in urban areas. Birds may have treated the yellow colour as aposematic, hence their avoidance of yellow feeders, whereas more visits were made to feeders in urban areas because fewer natural food resources are available there than in rural habitats.
\end{abstract}

Keywords Behaviour $\cdot$ Colour preference $\cdot$ Neophobia $\cdot$ Supplemental food $\cdot$ Urbanisation

\section{Zusammenfassung}

\section{Wie Vögel in der Stadt und auf dem Land auf die Farbe von Futterhäuschen reagieren}

Vögel können sich an urbane Lebensräume anpassen, indem sie ihr Suchverhalten ändern, um für sie neue, städtische Nahrungsquellen zu nutzen, die deutlich vielfältiger als auf dem Land sind. Neophobie—die Angst vor Neuem—kann dazu führen, dass neue Nahrungsquellen ungenutzt bleiben. Städtische Vogel-Populationen zeigen in der Regel weniger Neophobie als Populationen auf dem Land. Wir prüften die Reaktion von Vögeln in der Stadt und auf dem Land auf veschiedenfarbige Futterhäuschen. Eine Häuschenfarbe war grün (laut Literatur die Vorzugsfarbe), die andere gelb (angeblich die am meisten gemiedene). In dem von uns untersuchten Gebiet wurden in der Regel keine Futterhäuschen in diesen Farben benutzt; Futterhäuschen dort waren üblicherweise holzfarben. Nach unserer Theorie würden die gelben Häuschen eher von den Vögeln auf dem Land als von denen in der Stadt gemieden, weil die ersteren eine ausgeprägtere Neophobie zeigen würden. Den Winter über führten wir 22 Versuche in Städten und Dörfern in Ostzentral-Polen durch. Ein Zusammenhang zwischen Habitat und Häuschen-Farbe war praktisch Null (Anzahl Besuche an einem Häuschen, Bevorzugung eines Häuschens). Aber wir stellten eine geringere Anzahl Besuche an gelben Häuschen und häufigere Besuche an Häuschen innerhalb von Städten fest. Möglicherweise haben die Vögel die gelbe Farbe als aposematisch (Warnfärbung) empfunden und deshalb gelbe Futterhäuschen gemieden, während Futterhäuschen in städtischen Gebieten generell öfter besucht wurden, weil dort weniger natürliche Nahrungsquellen als in ländlichen Lebensräumen zur Verfügung stehen.

Communicated by F. Bairlein.

Artur Golawski

artur.golawski@uph.edu.pl

1 Faculty of Exact and Natural Sciences, Siedlce University of Natural Sciences and Humanities, Prusa 14, 08-110 Siedlce, Poland

\section{Introduction}

Urban areas are expanding rapidly worldwide because the human population is growing very fast, and many people are moving to such areas (UNDESA 2014). The effects of urbanisation have huge consequences for the 
life history, demography, communities and biodiversity of birds through the extinction of some species and changes in the distributions of others (Gil and Brumm 2013; Sepp et al. 2018). Birds can adapt to urban areas by modifying their behavioural responses (Sol et al. 2013; Audet et al. 2016; Marzluff 2017), for example, to predators or competitors (Beckerman et al. 2007; Hasegawa et al. 2010), and also their foraging tactics (Seress et al. 2011; Møller et al. 2015). Urban populations of some bird species have been found to exhibit less neophobia than rural populations of the same species, e.g. House Sparrow Passer domesticus and Common Myna Acridotheres tristis (Liker and Bókony 2009; Sol et al. 2011). Comprehensive studies in Poland have also shown a lesser degree of neophobia in assemblages of overwintering birds, such as Great Tit Parus major, in urban than in rural areas. The most probable explanation for this is that the urbanisation of birds involves the differential recruitment to urban habitats of individuals with lower levels of neophobia and earlier experiences with different food sources (Tryjanowski et al. 2016). Urban environments are rich in various sources of food for birds, such as refuse dumps, leftover pet food, waste human food and bird feeders (Tryjanowski et al. 2015; Ciach and Fröhlich 2017).

Neophobic behaviour may be influenced by the features of an object such as its colour (Gamberale-Stille et al. 2007), and many birds possess a preference for, or aversion to, food of different colours (Mastrota and Mench 1995). Many diurnal birds have the most complex (tetrachromatic) colour vision of all vertebrates and use it in every aspect of life, e.g. for recognising and discriminating objects (Osorio and Vorobyev 2008). Preferences for particular food colours have been reported in birds (Hartley et al. 2000; Duan et al. 2014), but studies relating to the colours of bird feeders have focussed mainly on the preferences of hummingbirds Trochilidae. Experimental studies at such feeders have not shown that hummingbirds consistently prefer one particular colour over another, although earlier studies did suggest a preference for red, because this colour was associated with the red flowers of nectar-rich plant species (Cronk and Ojeda 2008; Handelman and Kohn 2014). It is likely that other factors, such as location, previous experience and nectar quality, are more important in governing the choices of these birds. Apart from these studies of hummingbirds, only Rothery et al. (2017) demonstrated that garden birds in the UK preferred feeders of particular colours: higher numbers of several species visited silver and green feeders than red and yellow ones. Those authors stated that the former colours could have been preferred because feeders of these colours are often used in the UK, so the birds are familiar with them. There may, however, be a wider but unknown reason behind this preference for the colour green: Brown (2006) stated that tits preferred green nesting boxes to brown ones, yet brown is the colour of their natural nesting sites. The colour preferences of birds are, therefore, not well understood.

The aim of this paper was to examine the colour preference of two populations of birds: one that was exposed to novel items (urban), and the other not exposed to such items (rural-naïve), the hypothesis being that previous exposure affects the level of neophobia. We used bird feeders of two colours-yellow and green-in this investigation because birds are sensitive to these colours, and because of the results obtained by Rothery et al. (2017). We hypothesised that urban birds come into contact with novel, coloured objects such as bird feeders, garbage and other anthropogenic items more often than rural birds. Hence, we predicted that urban birds, potentially less neophobic, would feed more often at yellow feeders than their rural counterparts. For the same reason, birds in an urban habitat would not display a preference for any particular colour when approaching a feeder for the first time. We conducted the experiments in towns and villages in east-central Poland.

\section{Methods}

\section{Data collection}

Data were collected during December-February in the winters of 2018/2019 and 2019/2020 in 5 towns (urban) and 12 villages (rural) in east-central Poland. The populations of the towns (Siedlce, Węgrów, Sokołów Podlaski, Łuków, and Siemiatycze) ranged from 12600 to 78000 $($ mean $=31000)$, whereas the villages had from 136 to 550 $($ mean $=232)$ inhabitants (https://bip.gov.pl). Across the years, a total of 43 experimental trials, each in a different place (21 and 22 in rural and urban areas, respectively), were carried out in good weather, i.e. no snow or rain, or strong wind. The experimental sites were set up in places where small passerines, especially tits, were frequently observed, but no closer than $50 \mathrm{~m}$ from existing feeders. These sites were chosen during a slow drive around the study area. The minimum distance between two adjacent experimental sites was $1 \mathrm{~km}$. Two feeders of the same type were used in the experiment: they were shaped like a small house with a roof and were mounted on a $120 \mathrm{~cm}$-tall tripod. The two differently coloured feeders-one painted green and the other yellow (Śnieżka paint colours Nos. A425 and A450, respectively) - were placed $1 \mathrm{~m}$ apart. Each feeder was furnished with $50 \mathrm{~g}$ of sunflower seeds, the supply being replenished to that weight after each experiment.

Bird visits to the feeders were filmed on a video camera (SONY DCR-SR35) mounted on a tripod approximately $10 \mathrm{~m}$ from the feeders (Fig. 1). The observer, who was ca $50 \mathrm{~m}$ away, noted the time when the first bird turned up at either feeder, after which filming continued for another 


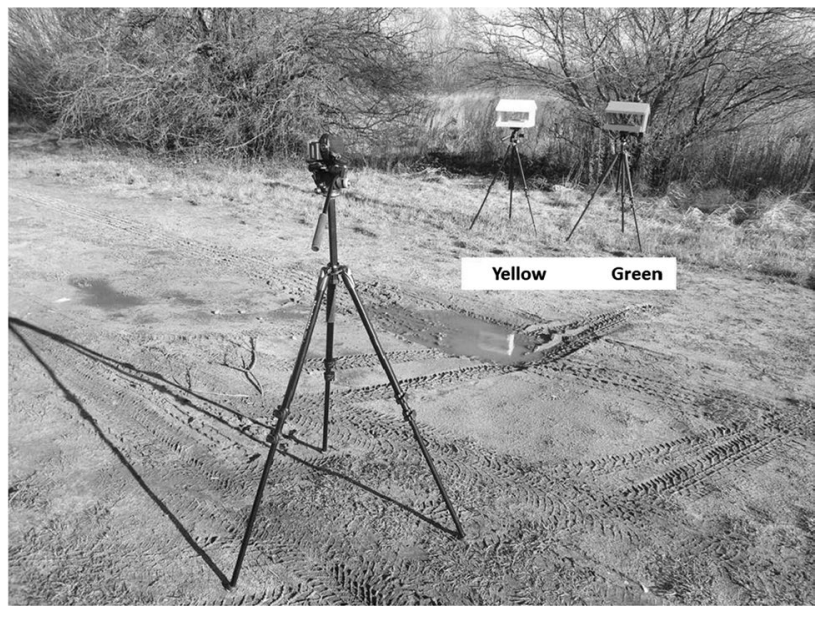

Fig. 1 Bird-feeders and video camera in the field

$15 \mathrm{~min}$. If birds did not begin feeding within $30 \mathrm{~min}$ of the experiment starting, it was ended. On any 1 day from 1 to 4 experimental trials $($ mean $=1.7$ ) were carried out, the exact number depending mainly on the time elapsing from the moment the experiment commenced until birds started feeding. A feeding visit was defined as a bird landing inside the feeder and taking a sunflower seed. The birds observed at the feeder were identified to species level. Great Tits visiting a particular feeder for the first time were also sexed. Birds visiting the feeders were not individually marked and so multiple visits by the same individual could not be accounted for. However, all sites were treated equally - we counted each visit separately (see also Peck et al. 2014; Tryjanowski et al. 2016; Rothery et al. 2017; Francis et al. 2018; Merrall and Evans 2020).

Before starting observations of activity at a feeder, we counted the birds within a radius of $50 \mathrm{~m}$ from it to quantify the composition of the local wintering bird community. For this, we used the point-count method with $5 \mathrm{~min}$ observations at each point, in which we counted all birds seen or heard, and a 2 min quiet period before each bird count. Prior to each experiment, we recorded the air temperature and presence/absence of snow cover; these factors were later included in the analyses, as they could have affected the behaviour and feeding of the birds (Krams et al. 2010; Golawski et al. 2015). In addition, we noted the time the experiment started (the first visit of a bird to a feeder), expressing this as the time after sunrise. The experiments were conducted between 08:16 and 15:55 h $($ mean $=12: 13 \mathrm{~h})$. The time of the experiment was taken into account because birds' feeding intensity, including their use of feeders, can change during the day (Bonter et al. 2013).

\section{Statistical analysis}

A general linear mixed model (GLMM) with a Poisson error structure and a log-link function was used to compare the total number of visits to the feeders between rural and urban sites. Habitat type (two levels: urban and rural), the colour of the bird feeders (two levels: yellow and green) and the interaction between these factors were introduced as fixed effects. Temperature, presence/absence of snow cover, time of experiment and the total number of birds yielded by the point count were also treated as fixed effects. A generalised linear model (GLM) with logit link function and binomial error distribution was used to compare the choice of the first feeder visited (yellow vs. green) by birds. Feeder colour [binomial variable: 0 -yellow (not preferred by birds), 1 - green (preferred by birds)] was the dependent variable. The fixed effects were temperature, presence/absence of snow cover, time of experiment and type of habitat (urban and rural). We checked the collinearity of the continuous variables in both models (GLMM and GLM) using variance inflation factors (VIF) (Quinn and Keough 2002): these were below the critical value of 10 , so we used all the variables in the models. All the statistical analyses were performed in SPSS v.21.0 (IBM Corp 2012); $P<0.05$ was considered statistically significant.

\section{Results}

The experimental bird feeders were visited by 4 species: Great Tit, Blue Tit Cyanistes caeruleus, Tree Sparrow Passer montanus and Greenfinch Chloris chloris (mean $=1.3$ species, $\mathrm{SE}=0.07$; range $1-2, n=43$ trials). The overwintering bird community around the feeders contained these same 4 species (mean $=2.1$ species, $\mathrm{SE}=0.14$; range $1-4, n=43$ trials). On average, their total numbers were 12.6 indiv. ( $\mathrm{SE}=1.85$ indiv., $n=22$ trials) in the urban habitats and 15.4 indiv. (2.26 indiv., $n=21$ trials) in the rural habitats. The numbers of the commonest species-Great Tit-were also similar in both habitats (urban $=9.7 \pm 1.66$ indiv., $n=22$ trials; rural $=8.0 \pm 0.80$ indiv., $n=21$ trials). The overwintering bird community around the feeders contained another eight species, but they are not analysed in this paper.

In 39 of the 43 experiments, Great Tit was the first species to visit the feeders ( 37 males, 1 female, 1 unsexed); in 3 of the other 4 experiments, it was Blue Tit and in 1, it was Tree Sparrow. GLM analysis did not show that the four fixed effects, i.e. temperature, presence/absence of snow cover, time of experiment, or habitat influenced the colour preferred by a bird on its first visit (Table 1). The green feeder was the first to be chosen in $55.8 \%$ of cases (all the percentages are naive estimates), the yellow one in $44.2 \%$. Although there was no significant effect of habitat, the birds 
Table 1 GLM of the predictors (air temperature, presence/absence of snow cover, time of experiment, habitat) affecting the colour (yellow vs. green) of the feeder first chosen by birds

\begin{tabular}{lrlll}
\hline Variable & Estimate & SE & Wald statistic & $P$ \\
\hline Intercept & 0.491 & 0.446 & 1.21 & 0.271 \\
Temperature & 0.101 & 0.131 & 0.59 & 0.441 \\
Snow cover: absent & 0.280 & 0.393 & 0.51 & 0.477 \\
Time of experiment & -0.021 & 0.203 & 0.01 & 0.919 \\
Habitat: rural & 0.425 & 0.350 & 1.48 & 0.224 \\
\hline
\end{tabular}

in the urban habitats more often paid their first visit to the green feeder than to the yellow one ( 63.6 vs. $36.4 \%$ of trials), whereas in rural habitats, feeders of both colours were visited first to an almost equal extent (47.6 vs. $52.4 \%$ of trials).

The total number of visits to both feeders at the experimental sites was 1899 (mean $=44.2, \mathrm{SE}=12.12$; range $1-482, n=43$ trials) and depended on two of the six factors analysed. The number of visits was higher in the urban than in the rural habitats (GLMM, $F_{1,78}=4.55, P=0.036$ ), and greater numbers of birds visited the green feeder than the yellow one (GLMM, $\left.F_{1,78}=14.09, P<0.001\right)$ (Fig. 2). The interaction between feeder colour and habitat (urban/rural) was not a significant predictor of the number of visits to a feeder, nor was there any effect of temperature, presence/ absence of snow cover and experimental time on the number of visits to feeders (Table 2).

\section{Discussion}

The study demonstrated that birds in both urban and rural habitats selected green feeders more often than yellow ones, and that bird visit rates were higher in the urban than in

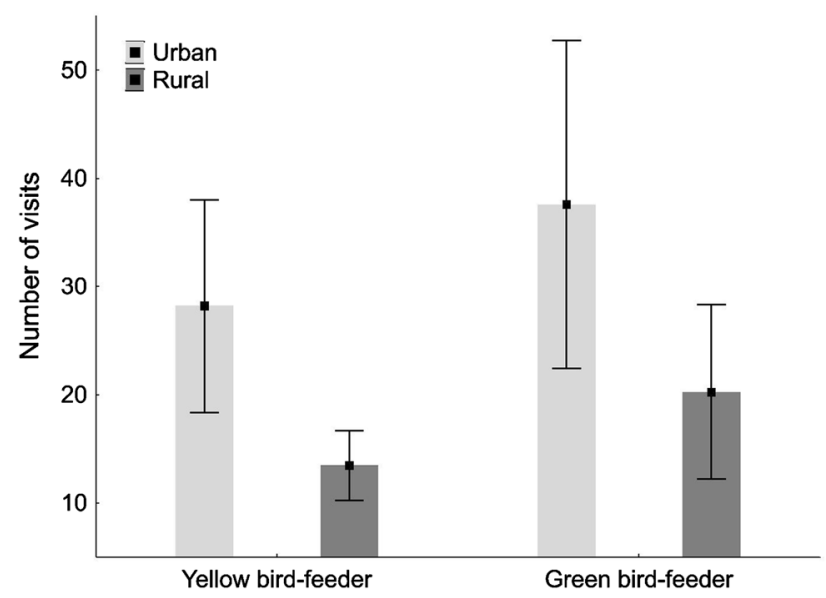

Fig. 2 Number (mean $\pm \mathrm{SE}$ ) of visits to bird feeders in relation to urbanisation and feeder colour ( $n=43$ experiments)
Table 2 GLMM for the number of birds using bird feeders in relation to air temperature, presence/absence of snow cover, time of experiment, number of birds around bird feeders, habitat (urban or rural), colour of bird feeders (green or yellow) and interaction between habitat and bird feeder colour as fixed effects

\begin{tabular}{lrlrl}
\hline Effects & Estimate & SE & \multicolumn{1}{l}{ t } & \multicolumn{2}{l}{$P$} \\
\hline Intercept & 1.820 & 0.920 & 1.98 & 0.042 \\
Temperature & -0.137 & 0.080 & -1.71 & 0.091 \\
Snow cover: absent & -0.053 & 0.472 & -0.11 & 0.911 \\
Time of experiment & 0.069 & 0.124 & 0.553 & 0.582 \\
Number of birds & 0.039 & 0.021 & 1.87 & 0.065 \\
Habitat: urban & $\mathbf{0 . 8 9 9}$ & $\mathbf{0 . 4 2 3}$ & $\mathbf{2 . 1 2}$ & $\mathbf{0 . 0 3 7}$ \\
Colour of bird feeders: yellow & $\mathbf{- 0 . 1 8 6}$ & $\mathbf{0 . 0 8 2}$ & $\mathbf{- 2 . 2 6}$ & $\mathbf{0 . 0 2 7}$ \\
Habitat $\times$ colour of bird feeders & -0.001 & 0.099 & -0.01 & 0.989 \\
\hline
\end{tabular}

Statistically significant terms are shown in bold

the rural habitats, regardless of feeder colour. The birds did not display a preference for any particular colour when approaching a feeder for the first time. But we found no dependence between the choice of feeder colour and habitat, which was meant to testify to the lower level of neophobia in the urban habitat. Our main hypothesis was thus not supported.

There may be several reasons why birds visited the green feeders more frequently than the yellow ones. Rothery et al. (2017), too, found that larger numbers of birds (including Great Tit - the most numerous species recorded in Poland) visited green and silver feeders significantly more often than yellow or red ones. Those authors suggested, however, that the preference for these colours could have been preferred because feeders of these colours are often used in the U.K., so the birds may simply have been accustomed to them. Likewise, birds on farms which often came into contact with animal feeds of different colours did not exhibit such strong neophobia towards bird feeders painted in new colours, suggesting experience is an important determinant of foraging behaviour (Lecuelle et al. 2011). Neophobia in relation to food colour has been well documented in birds (Hartley et al. 2000; Boogert et al. 2006; Sol et al. 2011). Meanwhile, in east-central Poland, we have never come across feeders painted green or yellow, and the birds clearly preferred one colour of feeders-green. Moreover, Brown (2006) stated that tits preferred green nesting boxes to brown ones, although the brown ones were delivered 1 year earlier and in greater numbers, so the birds were more familiar with them than with the green boxes. Some colours (e.g. yellow, red) are also associated with warning colouration and aposematism, and may be avoided by foraging birds (Exnerova et al. 2007; Dell'Aglio et al. 2016). This could be the most important reason why birds tended to avoid the yellow feeders. The preference for green, however, applied only to the frequency of visits to feeders, since the first visits to feeders 
in a particular place bore no relation to their colour, probably because of the relatively small sample size. What is certain is that the question of colour preferences of objects like feeders requires further research.

The fact that more visits were made to feeders in urban areas could have been because fewer natural food resources are available there than in rural habitats (Tryjanowski et al. 2016). It was more common for birds to find their food at feeders in the urban habitats than in the country, not only because there were more feeders in the former, but also because the numbers of particular types of feeder differed significantly between the urban and rural areas (Tryjanowski et al. 2015). Therefore, urban birds were not only potentially forced to seek food in feeders because of low natural food availability, but they were also more used to obtaining their food in this way (Chamberlain et al. 2009; Tryjanowski et al. 2015).

We had anticipated that rural birds, which come into contact with a smaller variety of places with food, should exhibit a higher level of neophobia than urban birds towards yellow feeders, which were also avoided by birds in other studies (Rothery et al. 2017). But this, the principal objective of our study, we failed to demonstrate: there was no interaction between the colour of a feeder and the surrounding habitat. It thus appears that the relationship between habitat (urban/rural) and bird behaviour, including neophobia, depends both on the species in question and on the birds' previous experience. The results of our study did not meet all our expectations, although they did confirm the preferences regarding feeder colour and the greater number of visits in urban areas, which is probably due to the limited availability of natural food. Admittedly, the sample was not very large, and the birds foraging at the feeders could have been counted more than once as they were not individually marked; in such an extensive area, this would not have been feasible. In some cases, where the intensity of foraging was the greatest, the choice of a particular feeder could have been suggested by the presence of other birds already at that feeder, so that the birds were forced, as it were, to take food from a feeder of the less preferred colour. Understanding the causes of colour preferences in combination with neophobia will be an inspiring challenge for future researchers.

Acknowledgements We are grateful to Peter Senn for the English language editing, as well as to Valentin Amrhein and two anonymous persons for their useful comments on a first version of the manuscript. The experiments comply with the current laws of Poland.

Author contributions AG and HS conceived the study. AG collected the data and performed the statistical analyses. AG and HS interpreted the results and wrote the manuscript.

Funding This work was supported by the Ministry of Science and Higher Education, Poland (topic number 75/94/s).
Data availability The datasets analysed during the current study are available from the corresponding author on reasonable request.

\section{Declarations}

Conflict of interest The authors have no competing interests.

Ethical approval No ethical approval was needed.

Open Access This article is licensed under a Creative Commons Attribution 4.0 International License, which permits use, sharing, adaptation, distribution and reproduction in any medium or format, as long as you give appropriate credit to the original author(s) and the source, provide a link to the Creative Commons licence, and indicate if changes were made. The images or other third party material in this article are included in the article's Creative Commons licence, unless indicated otherwise in a credit line to the material. If material is not included in the article's Creative Commons licence and your intended use is not permitted by statutory regulation or exceeds the permitted use, you will need to obtain permission directly from the copyright holder. To view a copy of this licence, visit http://creativecommons.org/licenses/by/4.0/.

\section{References}

Audet J-N, Ducatez S, Lefebvre L (2016) The town bird and the country bird: problem solving and immunocompetence vary with urbanization. Behav Ecol 27:637-644. https://doi.org/10.1093/ beheco/arv201

Beckerman AP, Boots M, Gaston KJ (2007) Urban bird declines and the fear of cats. Anim Conserv 10:320-325. https://doi.org/10. 1111/j.1469-1795.2007.00115.x

Boogert N, Reader S, Laland K (2006) The relation between social rank, neophobia and individual learning in starlings. Anim Behav 72:1229-1239. https://doi.org/10.1016/j.anbehav.2006.02.021

Bonter DN, Zuckerberg G, Sedgwick CW, Hochachka WM (2013) Daily foraging patterns in free-living birds: exploring the predation-starvation trade-off. Proc R Soc B 280:20123087. https://doi. org/10.1098/rspb.2012.3087

Browne SJ (2006) Effect of nestbox construction and colour on the occupancy and breeding success of nesting tits Parus spp. Bird Study 53:187-192. https://doi.org/10.1080/00063650609461432

Chamberlain DE, Cannon AR, Toms MP, Leech DI, Hatchwell BJ, Gaston KJ (2009) Avian productivity in urban landscapes: a review and meta-analysis. Ibis 151:1-18. https://doi.org/10.1111/j. 1474-919X.2008.00899.x

Cronk Q, Ojeda I (2008) Bird-pollinated flowers in an evolutionary and molecular context. J Exp Bot 59:715-727. https://doi.org/10. 1093/jxb/ern009

Ciach M, Fröhlich A (2017) Habitat type, food resources, noise and light pollution explain the species composition, abundance and stability of a winter bird assemblage in an urban environment. Urban Ecosyst 20:547-559. https://doi.org/10.1007/ s11252-016-0613-6

Dell'Aglio D, Stevens M, Jiggins CD (2016) Avoidance of an aposematically coloured butterfly by wild birds in a tropical forest. Ecol Entomol 41:627-632. https://doi.org/10.1111/een.12335

Duan Q, Goodale E, Quan RC (2014) Bird fruit preferences match the frequency of fruit colours in tropical Asia. Sci Rep 4:5627. https:// doi.org/10.1038/srep05627

Exnerova A, Stys P, Fucikova E, Vesela S, Svadova K, Prokopova M, Jarosik V, Fuchs R, Landova E (2007) Avoidance of aposematic 
prey in European tits (Paridae): learned or innate? Behav Ecol 18:148-156. https://doi.org/10.1093/beheco/arl061

Francis ML, Plummer KE, Lythgoe BA, Macallan C, Currie TE, Blount JD (2018) Effects of supplementary feeding on interspecific dominance hierarchies in garden birds. PLoS One 13(9):e0202152. https://doi.org/10.1371/journal.pone.0202152

Gamberale-Stille G, Hall KSS, Tullberg BS (2007) Signals of profitability? Food colour preferences in migrating juvenile blackcaps differ for fruits and insects. Evol Ecol 21:99-108. https://doi.org/ 10.1007/s10682-006-9126-8

Gil D, Brumm H (2013) Avian urban ecology. Oxford University Press, Oxford

Golawski A, Polakowski M, Filimowski P et al (2015) Factors influencing the fat load variation in three wintering birds species under the stable food access conditions. J Ethol 33:205-211. https://doi.org/ 10.1007/s10164-015-0433-9

Handelman C, Kohn JR (2014) Hummingbird color preference within a natural hybrid population of Mimulus aurantiacus (Phrymaceae). Plant Spec Biol 29:65-72. https://doi.org/10.1111/j.1442-1984. 2012.00393.x

Hartley L, Waas J, O'Connor C, Matthews L (2000) Colour preferences and coloured bait consumption by weka Gallirallus australis, an endemic New Zealand rail. Biol Conserv 93:255-263. https://doi. org/10.1016/S0006-3207(99)00143-3

Hasegawa M, Ligon RA, Giraudeau M, Watanabe M, McGraw KJ (2010) Urban and colorful male house finches are less aggressive. Behav Ecol 25:641-649. https://doi.org/10.1093/beheco/aru034

IBM Corp (2012) IBM SPSS Statistics for Windows, version 21.0 IBM Corp, Armonk

Krams I, Cirule D, Suraka V, Krama T, Rantala MJ, Ramey G (2010) Fattening strategies of wintering great tits support the optimal body mass hypothesis under conditions of extremely low ambient temperature. Funct Ecol 24:172-177. https://doi.org/10.1111/j. 1365-2435.2009.01628.x

Lecuelle S, Leterrier C, Chagneau A-M, Laviron F, Lescoat P, Bastianelli D, Bertin A, Bouvarel I (2011) Experience with a variety of feed colours reduces feed neophobia in the turkey. Appl Anim Behav Sci 135:78-85. https://doi.org/10.1016/j.applanim.2011. 08.007

Liker A, Bókony V (2009) Larger groups are more successful in innovative problem solving in house sparrows. Proc Natl Acad Sci 106:7893-7898. https://doi.org/10.1073/pnas.0900042106

Marzluff JM (2017) A decadal review of urban ornithology and a prospectus for the future. Ibis 159:1-13. https://doi.org/10.1111/ibi. 12430

Mastrota FN, Mench JA (1995) Color avoidance in northern bobwhites: effects of age, sex and previous experience. Anim Behav 50:519 526. https://doi.org/10.1006/anbe.1995.0266

Merrall ES, Evans KL (2020) Anthropogenic noise reduces avian feeding efficiency and increases vigilance along an urban-rural gradient regardless of species' tolerances to urbanisation. J Avian Biol 2020:e02341. https://doi.org/10.1111/jav.02341

Møller AP, Tryjanowski P, Diaz M, Kwieciński P, Indykiewicz P, Mitrus C, Golawski A, Polakowski M (2015) Urban habitats and feeders both contribute to flight initiation distance reduction in birds. Behav Ecol 26:861-865. https://doi.org/10.1093/beheco/ arv024

Osorio D, Vorobyev M (2008) A review of the evolution of animal colour vision and visual communication signals. Vision Res 48:2042-2051. https://doi.org/10.1016/j.visres.2008.06.018

Peck HL, Pringle HE, Marshall HH, Owens IPF, Lord AM (2014) Experimental evidence of impacts of an invasive parakeet on foraging behavior of native birds. Behav Ecol 25:582-590. https:// doi.org/10.1093/beheco/aru025

Quinn GP, Keough MJ (2002) Experimental design and data analysis for biologists. Cambridge University Press, Cambridge

Rothery L, Scott GW, Morrell LJ (2017) Colour preferences of UK garden birds at supplementary seed feeders. PLoS One 12(2):e0172422. https://doi.org/10.1371/journal.pone.0172422

Sepp T, McGraw KJ, Kaasik A, Giraudeau M (2018) A review of urban impacts on avian life-history evolution: does city living lead to slower pace of life? Glob Chang Biol 24:1452-1469. https://doi. org/10.1111/gcb.13969

Seress G, Bokony V, Heszberger J, Liker A (2011) Response to predation risk in urban and rural house sparrows. Ethology 117:896907. https://doi.org/10.1111/j.1439-0310.2011.01944.x

Sol D, Griffin AS, Bartomeus I, Boyce H (2011) Exploring or avoiding novel food resources? The novelty conflict in an invasive bird. PLoS One 6(5):e19535. https://doi.org/10.1371/journal.pone. 0019535

Sol D, Lapiedra O, Gonzalez-Lagos C (2013) Behavioural adjustments for a life in the city. Anim Behav 85:1101-1112. https://doi.org/ 10.1016/j.anbehav.2013.01.023

Tryjanowski P, Moller AP, Morelli F et al (2016) Urbanization affects neophilia and risk-taking at bird-feeders. Sci Rep 6:e28575. https://doi.org/10.1038/srep28575

Tryjanowski P, Skórka P, Sparks TH et al (2015) Urban and rural habitats differ in number and type of bird feeders and birds using supplementary food. Environ Sci Pollut Res 22:15097-15103. https:// doi.org/10.1007/s11356-015-4723-0

UNDESA (2014) World urbanization prospects: the 2014 revision, highlights, United Nations, Department of Economic and Social Affairs. Available at https://esa.un.org/unpd/wup/Publications/ Files/WUP2014Highlights.pdf. Accessed 08 Sept 2020

Publisher's Note Springer Nature remains neutral with regard to jurisdictional claims in published maps and institutional affiliations. 